\title{
RELATIONSHIPS BETWEEN HUMAN RESOURCE MANAGEMENT PRACTICES, BUSINESS STRATE- GY FIT AND FIRM PERFORMANCE
}

\author{
Oya Erdil \& Ayşe Günsel \\ Gebze Institute of Technology, Turkey
}

\begin{abstract}
While there has been growing interest concerning the relationship between human resource (HR) practices, firm strategy and firm performance, limited research attention has been paid providing empirical evidence in support of them. This study investigates the relationships between HR practices, human resources management (HRM) - firm strategy fit and the firm performance of 63 small and medium sized firms located around Kocaeli and Gebze from both theoretical and empirical perspective. The findings indicate a strong relationship between different $H R$ practices and HRM-firm strategy fit and firm performance. Further, the results provide support for the assertion that HR-firm strategy fit can significantly assist a firm in improving performance. Therefore, empirical support is obtained for the efforts at aligning HRM practices with firm strategy and firm performance.
\end{abstract}

\section{INTRODUCTION}

Global rivalry, shorter product life cycles, and unstable product and market environments have contributed to a new business world that offers some interesting challenges and opportunities to organizations. Established competitive mechanisms have become less useful response, and therefore firms continuously seek for newer sources of competitive advantage, one of the most important being human resource management (HRM) (Jayaram et alL.,1999:1; Terpstra, 1994: 13). Survival and success of organizations increasingly depend on their ability to build highly skilled work forces and to release the full potential of their human resources. Accordingly, within the last two decades, there have been a variety of important developments in the literature concerning the issues pertaining to the management of people and significant attention has been directed towards HRM practices (Haris and Ogbonna, 2001:158). HR practitioners have become busy with indicating the value of the HRM, mostly through showing its impact on firm performance (Rogers and Wright, 1998: 311).

Studies linking strategy and HRM generally emphasize people-related activities that companies perform. This involves an essential assumption that all HR practices (recruitment, development, etc.) share the same basic character and play a similar kind of role in relation to strategic management (Luoma, 2000: 771). Effective HRM strategy systematically organizes all individual HRM measures to directly influence employee attitude and behavior in a way that leads business to achieve its competitive strategy. (Huang, 2001: 134).

In view of the fact that the goals and necessities of each of the competitive strategy types are different, the management of the human resources of the firm should be in line with the firm's overall strategy. This means that HRM carries the promise that if people are regarded and managed as strategic resources, the firm can obtain a competitive advantage and thus achieve superior performance (Heijltjesa and Witteloostuijn, 2003: 33). Accordingly, there has been a variety of studies in the literature concerning the nature of the relationship between business strategy, human resource management and firm performance (Kelliher and Perret, 2001: 421).

Although the literature suggests that the link between HR practices and firm performance is quite positive, it is nevertheless not necessarily a direct relationship (Lau and Ngo, 2004). Regarding which HR practices are relevant, the literature often focuses on bundles of HR practices as determinants of firm performance. (Wright et all., 1997; Lepak et all., 2005).

In this study the effects of five groups of HR practices on firm performance are analyzed. The bundle of HR practices is: selective hiring, use of teams and decentralization, incentive on performance, training and sharing information. These HR practices are adopted from the study by Ahmad and Schroeder (2003). Firm performance scale measures overall organizational performance including market share, growth and success. The effects of the HR practices on HRM-firm strategy fit (alignment) are also analyzed on the study.

\section{THEORETICAL BACKGROUND}

\section{Human Resource Management}

From a strategic perspective, resource-based view 
(RBW), suggests that resource advantage of valuable knowledge, unique skill sets, and decision-making capability result in a firm's competitive advantage within the market place (Offstein et all., 2005). The RBW was originally proposed to shift from an organizational product perspective to a resource perspective to better explain strategic management of business. This approach assumes that resources exist heterogeneously among firms and there is a significant cost for the transfer of resources. These two characteristics lead to competitive advantage (Gowen III and Tallon, 2005).

The RBW`s main assumption holds that only resources that are valuable, rare, inimitable and sustainable are capable of generating superior performance. Such resources are considered to be strategic and intangible assets in addition to reputation and tangible assets (Galbreath, 2005; Fahy, 2002). Accordingly, within the last two decades, there have been numerous important developments in the literature coping with issues concerning the management of human resources (Haris and Ogbonna,158); and researchers have suggested that the human resources function is an organizational resource that can, and should, contribute to the firm level competitive advantage and value creation (Rochling et all, 2005). Therefore, from a resource based view, an appropriate HR system creates and develops organizational capabilities that become sources of competitive advantage (Lou and Ngo, 2004).

Intensive competition, shorter product life cycles and volatile product and market environments have contributed to the complexity faced by businesses. These changes in global economic environment which is emerging will present some interesting challenges and opportunities to organizations. Some organizations will go under, some will continue to exist and some will not only continue but flourish. As a result, firms constantly search for newer sources of competitive advantage, one of the most important being human resource management (HRM) that has the potential to improve and sustain organizational performance and determine the organization's fate (Jayaram, 1991; Terpstra, 1994: 13)

Recent academic research has attempted to demonstrate the impact of HRM on firm performance and the relationship between the practices and firm outcomes is discussed best in the strategic human resource management literature (Pfeifer, 1998, Rogers and Wright, 1998). Early studies linked individual HR practices such as training, selection, performance appraisal and compensation to firm financial performance
(Milkovich, 1992; Huselid, 1995, Guest, 1997). Traditional HRM factors alone are no longer sufficient in maintaining firm strategy. Even though HR departments have historically been bureaucratic functions within organizations, its role has been focused on pursuing more flexible and creative means to deliver services in constantly changing environments (Lepak et al., 2005). HR professionals are increasingly expected to become much more responsive, efficient, and ultimately make a strategic contribution to their company.

Designing and integrating human resources systems is one of the ways to ensure the creation of value for customers and sustain organizational effectiveness. The notion of best practices in human resource management has received a lot of attention in recent years. It has been suggested that there is a universal set of human resource best practices that can maintain a firm's performance (Lau and Ngo, 2004). There is growing evidence that corporate HRM practices are associated with high (financial) performance and can encourage employee behavior and attitudes towards strengthening the competitive strategy of an organization (Hiltrop, 1996). Due to external and internal forces, various contingencies can be found which put identifying "best practice" into question. However, today's more effective HR managers look for information and ideas on best practices and they ignore paradoxes that mask the truth about best practice. One of the three paradoxes identified by Fitzen (1997) is the expectation of managers to find simple solutions to today's complex business problems. The second paradox is that the visible program is neither generalizable nor a best practice. In most cases, follow-up studies show that the practice was not repeatable with the same or better results. Final paradox is the irony of seeking enlightenment about the future from studying the past. For instance, some HR practices are related to financial outcomes while some others may relate more to staff turnover (Lau and Ngo, 2004).

Another question is whether diverse HRM practices will result with different effects on organizational performance. For example, Lieberman et al. found that Japanese auto producers achieved higher productivity after they had adopted better HRM methods. Likewise, Kelly and London (1989) pointed out that the essential role played by HRM methods in Taiwan, Korea, Singapore, and Thailand had supported the global competitiveness of these countries. As well, some scholars pointed out that the adoption of different HRM methods resulted with different effects on organizational performance (Huang. 2001:133). 
As mentioned above, there have been many studies regarding the best practice issue in the literature. Successful firms create a bundle of employee practices to reinforce the organizations 'strategic position (Enz, Signaw, 2000). Among many others Hiltrop (1999), in his research asked the HR managers and personnel officers in 319 companies in western Europe about HR policies and practices of their firm and found out that employment security, opportunities for training and development, recruitment and selection from within, career development and teamwork, participation and proactive personnel planning as the most important practices. In fact the role of HR is to acquire, develop, manage, motivate and gain the commitment of the employees. The focal point is how to determine the best practice in various HR-related decisions (Baruch, 1998). In a comprehensive study on best practices in the lodging industry Enz and Signaw (2000) examined five categories of HR best practices; i-) leader development, ii-) training and knowledge building, iii-) employee empowerment, iv-) employee recognition and $\mathrm{v}-$ ) cost management. In a similar fashion, Jayaram (1999: 5) states that the broad range of human resource management practices affecting performance can be classified into five major topics: i) Top management commitment; ii-) Communication of goals; iii) Employee training; iv) Cross functional teams; and v) General HRM practices. This classification implies that human resource management practices can be analyzed using the five broad groupings of practices (Jayaram, 1999:5). On the other hand Pfeffer (1998) has proposed seven HRM practices that are expected to enhance organizational performance. The practices offered by Pfeffer (1998: 96) are:

1) Employment security

2) Selective hiring of new personnel

3) Self-managed teams and decentralization of deci sion making as the basic principles of organization al design.

4) Comparatively high compensation contingent on organizational performance

5) Extensive training

6) Reduced status distinctions and barriers, including dress, language, office arrangements, and wage dif ferences across levels

7) Extensive sharing of financial and performance information throughout the organization. (Ahmad and Schroeder: 19).

In knowledge based competitive economy, the adoption of appropriate HRM practices is important to ensure effective strategy implementation. HRM practices create procedures that constitute the building of employees` knowledge and skills throughout the organization to promote valued and unique organizational competencies which support competitive advantage (Werbel and DeMarie, 2005). Strategic human resource management has become a more central issue to management literature from empirical research view linking HRM practices with firm performance and profitability (Delaney and Huselid, 1996; Huselid, 1995; Becker and Gerhart, 1996). Several researchers have attempted to create such categories. For instance, Huselid (1995), Jackson and Schuler (1997) suggested that HR practices are strategic or technical in nature. Another classification outlined three domains of HR operational, relational and transformational. As noted by Wright and colleagues (1997), HR practices may be viewed as transactional, traditional or transformational. Viewed in combination HR practices can be ranged from being transactional (administrative) to transformational (strategic) in nature (Lepak et al., 2005).

\section{HRM and Business Strategy}

There is a close connection between human resources management and firm strategy, which in turn refers to the business environment and organizational development. (Grundy, 1997: 474-475). It is widely accepted that a company's human resource management (HRM) practices should be matching to the strategy of the whole company. Although nobody disagrees with the importance of such a correlation, the deeper nature of this relationship takes remarkably little attention (Luoma, 2000: 769). HRM implies that if people are considered and managed as valuable strategic resources, the firm can achieve a competitive advantage and as a consequence demonstrate superior performance (Pfeffer, 1998). This means that the management of human resources should be corresponding to the firm strategy, as the goals and prerequisites of each of the strategy profiles are different (Heijltjesa and Witteloostuijn: 2003: 33).

The assumption of a close link between business strategy and HRM methods is based on contingency theory. This theory underlines that HRM methods are selected in accordance with the type of competitive strategy adopted by a business (Huang, 2001; Lepak et al., 2005) It assumes that companies that coordinate their business strategy and HRM activities achieve better performance than companies that do not. Since the HR function is transforming its focus from management of human resources to the maintenance of organizational effectiveness, organizational capabilities are deeply rooted in human resource capabilities; HR is best positioned to deliver these outcomes. Here the contingency approach is considered to be useful because a set of organizational capabilities that leads to effectiveness is likely to depend on a host of orga- 
Figure 1 Strategic Fit Model

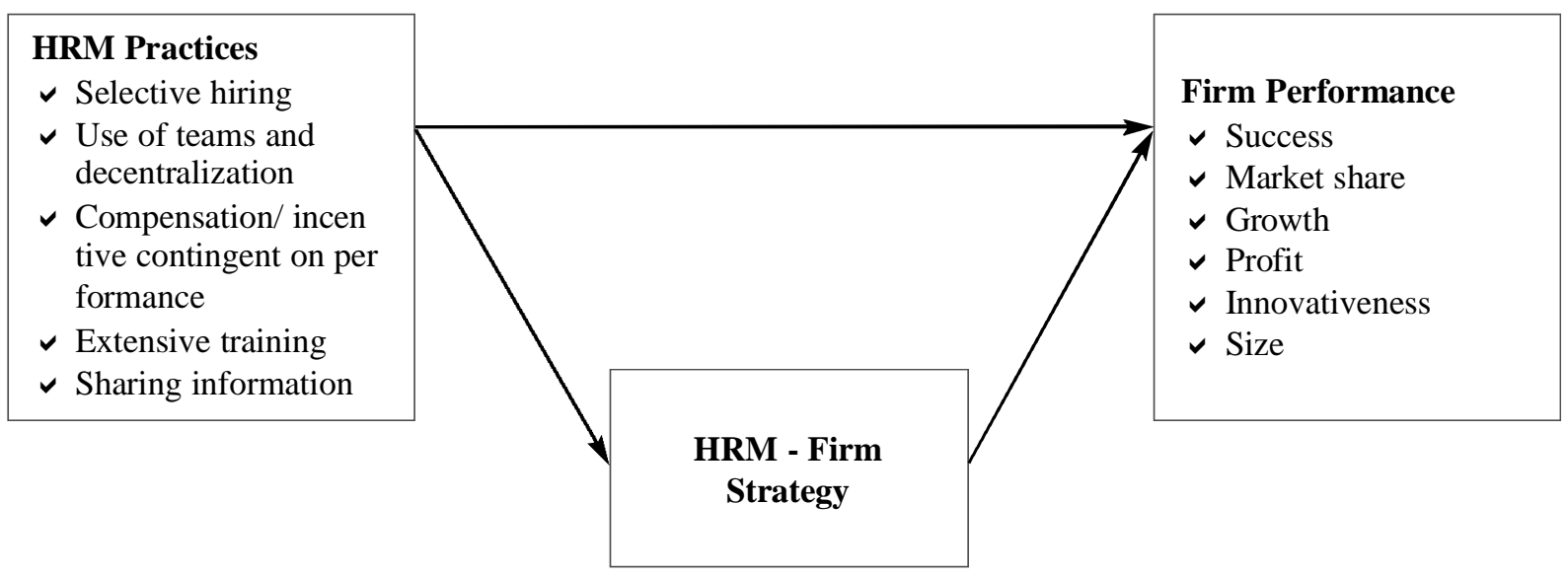

Fig. 1. Research model

nizational, strategic, and environmental characteristics (Roehling et al., 2005).

In accordance with theoretical explanations, the proposed relationships between HRM practices, HRMfirm strategy fit and firm performance are shown in fig. 1.

\section{RESEARCH \\ METHODOLOGY \\ AND FINDINGS \\ Data and Measures}

The aim of this study is to demonstrate the relationships between the HRM practices, HRM-firm strategy fit and firm performance. In order to empirically investigate these relationships, small and medium sized firms located around Gebze were surveyed. The study is based on the administration of using the documents obtained from Gebze Chamber of Commerce and Kocaeli Chamber of Industry, 300 firms among 1000 were identified as the sample group of the research because of their availableness. Tools such as e-mail, letter and face to face interviews were used for gathering data. One middle manager from each company had received the survey. Therefore, the sampling frame for the study was a list of 300 manufacturing and service firms among which a total of 63 questionnaires has been returned. All constructs were measured with already existing and reliable scales. All items were measured on a seven point Likert-type scale where $1=$ strongly disagree and $7=$ strongly agree. Data is evaluated through SPSS 9.0. The relationships between the variables are tested using correlation, reli- ability, regression and factor analyses. The mean age of the participants was 33.27 (s.d. =5.58); the proportion of women, $9,8 \%$, and married $69,5 \%$. Of the participants, $\% 61$ had university education and $\% 17$ had master education. $75,78 \%$ of the respondents were from manufacturing industry; $24,22 \%$ of the participants were from service industry.

HRM -Firm Strategy Fit: HRM -firm strategy fit was measured with a five-item scale developed and validated by Huselid (1997). The measure covers the degree of fitness between the firm strategy and HRM practices.

Firm Performance: The scale used to measure firm performance is based on Choi and Lee`s (2003) model consisting of six items. Overall firm performance was measured with items including success, market share, growth, innovativeness, profit and firm size. 


\section{Scales}

\section{TABLE 5 ITEMS EMERGED IN THE MISSION STATEMENTS OF SOCIALLY RESPONSIBLE COMPANIES}

\begin{tabular}{|c|c|c|}
\hline HRM PRACTICES & & \\
\hline \multirow[t]{2}{*}{ Selective hiring } & $\begin{array}{l}\text { Manufacturing and } \\
\text { human } \\
\text { resources fit }\end{array}$ & $\begin{array}{l}\text { Manufacturing and human resources } \\
\text { fit was measured using six items adopted } \\
\text { from Ahmad and Schroeder`s (2003) study. }\end{array}$ \\
\hline & $\begin{array}{l}\text { Behavior and } \\
\text { attitude }\end{array}$ & $\begin{array}{l}\text { Behavior and attitude was measured using } \\
\text { three items adopted from Ahmad and } \\
\text { Schroeder`s (2003) study. }\end{array}$ \\
\hline \multirow[t]{2}{*}{$\begin{array}{l}\text { Use of teams and } \\
\text { decentralization }\end{array}$} & Team activities & $\begin{array}{l}\text { Team activities was measured using } \\
\text { five items adopted fromAhmad and } \\
\text { Schroeder`s (2003) study. }\end{array}$ \\
\hline & $\begin{array}{l}\text { Interaction } \\
\text { facilitation }\end{array}$ & $\begin{array}{l}\text { Interaction facilitation was measured using } \\
\text { three items adopted from Ahmad and } \\
\text { Schroeder`s (2003) study. }\end{array}$ \\
\hline $\begin{array}{l}\text { Compensation/ incentive } \\
\text { contingent on performance }\end{array}$ & $\begin{array}{l}\text { Incentives to meet } \\
\text { objectives }\end{array}$ & $\begin{array}{l}\text { Incentives to meet objectives was measured } \\
\text { using three items adopted from Ahmad and } \\
\text { Schroeder`s (2003) study. }\end{array}$ \\
\hline \multirow[t]{2}{*}{ Extensive training } & $\begin{array}{l}\text { Training on } \\
\text { job skills }\end{array}$ & $\begin{array}{l}\text { Training on job skills was measured using } \\
\text { three items adopted from Ahmad } \\
\text { and Schroeder`s (2003) study. }\end{array}$ \\
\hline & $\begin{array}{l}\text { Training in } \\
\text { multiple functions }\end{array}$ & $\begin{array}{l}\text { Training in multiple functions was } \\
\text { measured using four items adopted from } \\
\text { Ahmad and Schroeder`s (2003) study. }\end{array}$ \\
\hline \multirow[t]{2}{*}{ Sharing information } & $\begin{array}{l}\text { Communication } \\
\text { of strategy }\end{array}$ & $\begin{array}{l}\text { Communication of strategy was } \\
\text { measured using four items adopted from } \\
\text { Ahmad and Schroeder`s (2003) study. }\end{array}$ \\
\hline & $\begin{array}{l}\text { Feedback } \\
\text { on performance }\end{array}$ & $\begin{array}{l}\text { Feedback on performance was measured } \\
\text { using four items adopted from } \\
\text { Ahmad and Schroeder`s (2003) study. }\end{array}$ \\
\hline
\end{tabular}

Table 1. HR practices used in the study adopted from Ahmad and Schroeder (2003) Team activities was measured using

\section{Analysis}

Since the scales were used with a new sample, 46 items were submitted to exploratory factor analysis. A principal component analyses and scree plot indicated that 11 factors should be retained (eigenvalues above1.0). The best fit of data was obtained with a principal factor analysis with varimax rotation. 
Table 2. Factor analyses

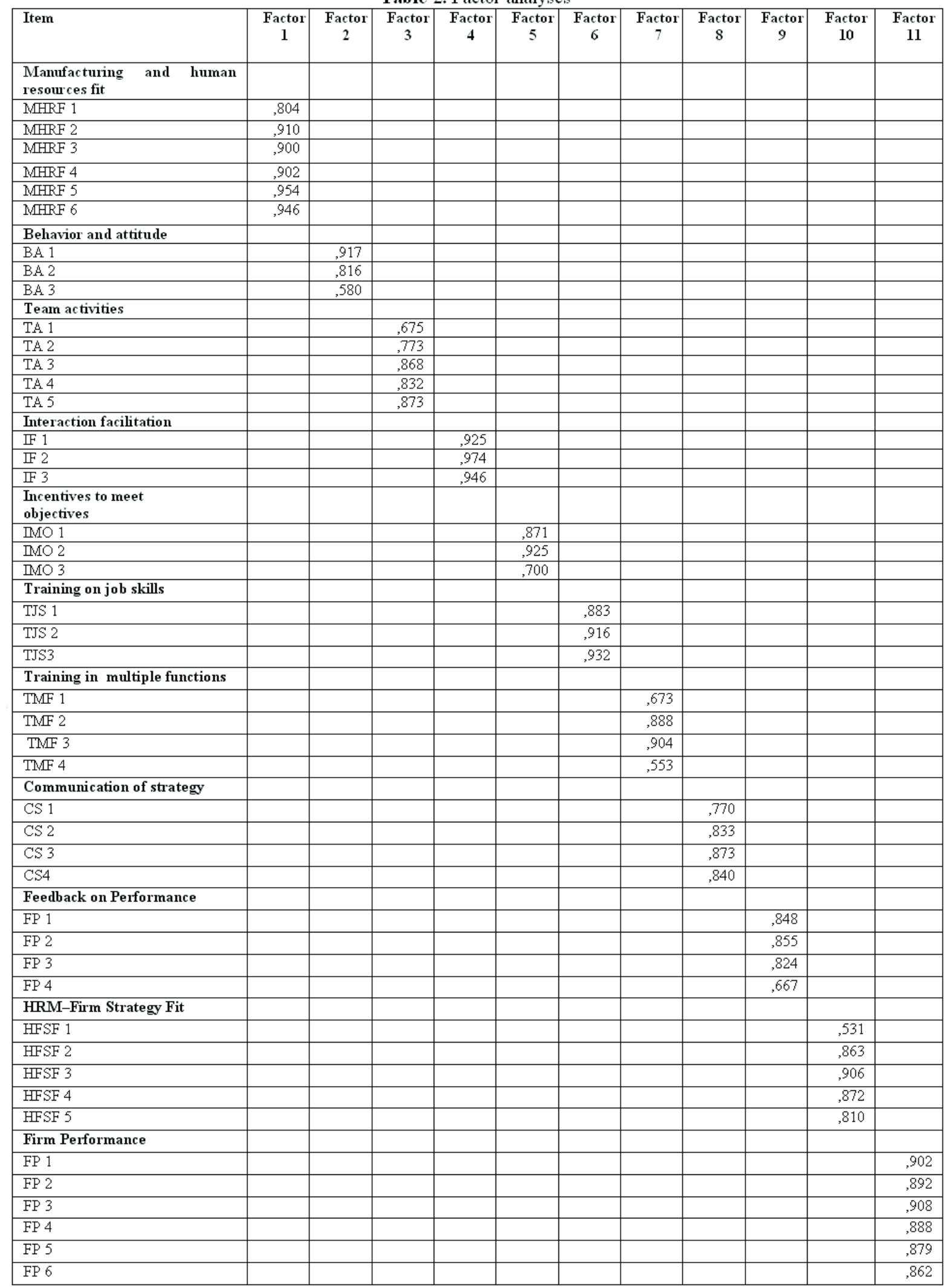


Table 3. Standard deviations and correlations

\begin{tabular}{|c|c|c|c|c|c|c|c|c|c|c|c|c|c|}
\hline & $\begin{array}{l}\text { Mean } \\
\text { Value }\end{array}$ & $\begin{array}{l}\text { Standard } \\
\text { Deviation }\end{array}$ & $\mathbf{1}$ & 2 & 3 & 4 & 5 & 6 & 7 & 8 & 9 & 10 & 11 \\
\hline $\begin{array}{l}\text { Manufacturing and } \\
\text { human resources fit }\end{array}$ & 3,4206 & 1,25290 & $(, 95)$ & & & & & & & & & & \\
\hline $\begin{array}{l}\text { Behavior and } \\
\text { attitude }\end{array}$ & 4,1534 & ,68477 & $297^{*}$ & ,67) & & & & & & & & & \\
\hline Team activities & 3,5778 &, 75067 &, $680^{* *}$ &, $582^{\star *}$ & 86) & & & & & & & & \\
\hline $\begin{array}{l}\text { Interaction } \\
\text { facilitation }\end{array}$ & 4,1693 &, 72060 &, $542^{* *}$ &, $430^{* *}$ &, $790^{\star \star}$ & $(, 91)$ & & & & & & & \\
\hline $\begin{array}{l}\text { Incentives to meet } \\
\text { objectives }\end{array}$ & 3,1058 & 1,23397 &,- 018 &, 036 &, 017 &, $487^{\star \star}$ & $(, 77)$ & & & & & & \\
\hline $\begin{array}{l}\text { Training on job } \\
\text { skills }\end{array}$ & 3,4021 &, 92003 &, $377^{* *}$ &, $296^{*}$ & $653^{* t}$ &, $458^{* \star}$ &, 088 & $(, 89)$ & & & & & \\
\hline $\begin{array}{l}\text { Training in multiple } \\
\text { functions }\end{array}$ & 3,5754 &, 76548 &, $729^{* *}$ &, $560^{* *}$ &, $862^{* *}$ & $630^{\star *}$ &,- 027 &, $729^{* *}$ & $(, 71)$ & & & & \\
\hline $\begin{array}{l}\text { Communication of } \\
\text { strategy }\end{array}$ & 4,0298 &, 70451 &, $359^{\star *}$ & $319^{*}$ &, $474^{* *}$ &, $719^{\star *}$ &, $521^{\star \star}$ & $488^{* *}$ &, $342^{* \star}$ & $(, 84)$ & & & \\
\hline $\begin{array}{l}\text { Feedback on } \\
\text { performance }\end{array}$ & 2,2857 &, 89505 &, $418^{* *}$ &,- 016 &, $353^{\star *}$ &,- 041 &,$- 513^{\star \star}$ & ,190 &, $362^{\star \star}$ &,- 162 & $(, 81)$ & & \\
\hline $\begin{array}{l}\text { HRM-Firm } \\
\text { Strategy Fit }\end{array}$ & 3,1508 & ,97001 &, $604^{*+}$ &, $404^{* *}$ &, $810^{\star \star}$ &, $750^{\star \star}$ & ,118 &, $595^{\star \star}$ & $551^{\star \star}$ & $621^{\star \star}$ & ,161 & $(, 85)$ & \\
\hline Firm Performance & 3,8095 & ,91525 &, $553^{\star *}$ &, $601^{\star *}$ &, $740^{\star \star}$ &, $660^{\star \star}$ & 213 & $637^{\star \star}$ &, $711^{\star \star}$ &, $534^{\star \star}$ &,- 199 &, $688^{\star \star}$ & $(, 94)$ \\
\hline
\end{tabular}

The results of factor analysis reveal factor structures consistent with expectations. Specifically HR practices fall into five distinct factors. The first reflects what may be referred to one of the traditional HR practices, selective hiring, including manufacturing fit and human resource fit, and behavior and attitude sub dimensions. Manufacturing and human resources was measured with six items and the internal consistency of this factor was 0, 9531 (alpha). Factor 2 which is behavior and attitude dimension, includes three items with internal consistency reliability coefficient (alpha) of 0,6708 . The internal consistency estimate of all other four HR practices and their components were all at acceptable levels: team activities (five items) alpha $=0.8611$; interaction facilitation (three items) alpha $=0.9197$; incentives to meet objectives (three items) alpha $=0,7789$; training on job skills (three items) alpha $=0,8916$; training in multiple functions (four items) alpha $=0,7179$; communication of strategy (four items) alpha $=0,8445$; feedback on performance (four items) alpha $=0,8125$; HRM- firm strategy fit (five items) alpha $=0,9435$.

Mean values, standard deviations and inter-correlations were summarized in Table 3. Cronbach`s Alpha values were shown using parentheses on the cross of the table. On a bivariate level, firm performance was positively related to manufacturing and human resources fit, behavior and attitude, team activities, interaction facilitation, training on job skills, training in multiple functions, communication of strategy and HRM-firm strategy fit. Similarly, HRM- firm strategy fit was positively related to manufacturing and human resources fit, behavior and attitude, team activities, interaction facilitation, training on job skills, training in multiple functions, communication of strategy.
However, the correlation results indicate that, there is no direct relationship between incentives to meet objectives, feedback on performance and HRM-firm strategy fit, and firm performance

\section{Regression Analyses}

In the regression analysis shown in Table 4, we investigated the influences of HRM practices together on HRM-firm strategy fit. The regression model is significant as a whole $(\mathrm{F}=14.432,: \mathrm{p}<0,01)$; it explains $\% 19,3$ of the change of HRM-firm strategy fit. The findings indicate that manufacturing and human resources fit, behavior and attitude, team activities , interaction facilitation, ,training on job skills have positive and significant effects on HRM-firm strategy fit. However, incentives to meet objectives, training in multiple functions, communication of strategy and feedback on performance were found to have negative

Table 4. Regression results for HRM practices and HRM-firm strategy fit.

\begin{tabular}{|l|l|l|}
\hline INDEPENDENT VARIABLES & $\beta$ & Sig \\
\hline Manufacturing and human resources fit &, $683^{* *}$ &, 003 \\
\hline Behavior and attitude &, $302 * *$ &, 000 \\
\hline Team activities &, $431 * *$ &, 000 \\
\hline Interaction facilitation &, $798^{* *}$ &, 000 \\
\hline Incentives to meet objectives &,$- 274 * *$ &, 000 \\
\hline Training on job skills &, $885^{* *}$ &, 000 \\
\hline Training in multiple functions &,$- 539 * *$ &, 000 \\
\hline Communication of strategy &,$- 269 * *$ &, 000 \\
\hline Feedback on performance &,$- 034 * *$ &, 000 \\
\hline Dependent variable: HRM-Firm Strategy Fit, $\mathrm{R} 2=0.193 \quad, \quad \mathrm{~F}=14.432$ \\
\hline
\end{tabular}


Table 5. Regression results for the effects of HRM practices and HRM-firm strategy fit

\begin{tabular}{|l|l|l|}
\hline INDEPENDENT VARIABLES & $\beta$ & Sig \\
\hline Manufacturing and human resources fit &, $361^{* *}$ &, 000 \\
\hline Behavior and attitude & $080^{* *}$ &, 000 \\
\hline Team activities &, 833 &, 258 \\
\hline Interaction facilitation &, $398^{*}$ &, 000 \\
\hline Incentives to meet objectives &,$- 008^{*}$ &, 013 \\
\hline Training on job skills &, 212 &, 910 \\
\hline Training in multiple functions &, $017^{*}$ &, 043 \\
\hline Communication of strategy &, 051 &, 906 \\
\hline Feedback on performance &,- 701 &, 559 \\
\hline Dependent variable: Firm performance, R2 $=0.356, \mathrm{~F}=18,84$ \\
\hline
\end{tabular}

effects on HRM-firm strategy fit. Amongst all practices, the impact of training on job skills on HRM-firm strategy fit was the highest one; it is followed by interaction facilitation and manufacturing and human resources fit.

In the regression analysis shown in Table 5, we investigated the influences of HRM practices together on overall firm performance. The regression model is significant as a whole $(\mathrm{F}=18,84: \mathrm{p}<0,01)$; it explains $\% 35$ of the change of firm performance. These results provide empirical evidence that HRM strategies are related with firm performance. The findings indicate that manufacturing and human resources fit, behavior and attitude and training in multiple functions have positive and significant effects on firm strategy. However, interaction facilitation and incentives to meet objectives were found to have negative effects on firm performance. Moreover, there was no significant relationship between training on job skills, communication of strategy, feedback on performance and firm performance. Amongst all practices, the impact of manufacturing and human resources fit on firm performance was the highest one.

Table 6. Regression results for the effects of HRM-firm strategy fit on firm performance

\begin{tabular}{l}
\begin{tabular}{|l|l|l|}
\hline INDEPENDENT VARIABLES & $\beta$ & Sig \\
\hline HRM-Firm Strategy Fit &, $688 * *$ &, 000 \\
\hline Dependent variable: Firm performance, $\mathrm{R} 2=0.474, \mathrm{~F}=34,49$ \\
\hline$* *: \mathrm{p}<0,01, *: \mathrm{p}<0,05$
\end{tabular} \\
\hline
\end{tabular}

In the regression analysis shown in Table 6, we investigated the influences of HRM-firm strategy fit on firm performance. The regression model is significant as a whole $(\mathrm{F}=34,49: \mathrm{p}<0,01)$; it explains $\% 48$ of the change of firm performance. HRM-firm strategy fit is associated positively and significantly with firm performance.

\section{DISCUSSION AND CONCLUSIONS}

Our findings related to the direct effect between HRM practices and firm performance is consistent with the results from prior research (eg. Ahmad and Schroeder, 2003). Selective hiring which is the combination of both manufacturing and human resource fit and behavior and attitude plays a significant role in enhancing organizational performance. Selection plays a critical role in implementing firm strategy and is designed to employ people with desired skills and behaviors needed to match a work with context and improve performance (Werbel and DeMarie, 2005).

Previous studies identified training efforts as one of the primary factors to improve organizational performance (Lau and Ngo, 2004; Wimbush, 2005). The finding that there is a strong link between training in multiple functions and organizational performance is worthy of further exploration. However the finding that training on job skills dimension is not found to be related to firm performance in the regression analysis for the sample firms in the survey implies the need for further research with larger samples. The aim of training and development is to provide information and support that enables employees to overcome job-related difficulties and achieve job performance (Weber and DeMarie, 2005) and organizational performance as a whole (Valle et all., 2000).

The finding that the use of teams and decentralization is significantly but negatively related to firm performance indicates inconsistent result with previous research. It is not easy to attribute a simple explanation to these findings. Team activities within the firms in the sample need to be improved further for better performance. Research on innovativeness suggests that team-based work is closely linked to innovative performance (Lau and Ngo, 2004). Our finding regarding non-existence of association between team work and firm performance would be explained by the overall performance measurement used in the study. Nevertheless, in their study, Lau and Ngo (2004) found that team development and performance-based reward were not significantly related to innovation outcome which is inconsistent with the previous research.

In terms of communication of strategy and feedback on performance which are sub dimensions of sharing information, results indicate that there exists no significant relationships between communication of strategy and firm performance. These empirical findings are contrary to the tendencies suggested by the literature. 
These empirical findings may be summarized as the following: first, that there are significant relationships between the selection and firm performance, and training and firm performance. These two traditional HR practices therefore are significantly related to firm performance. However, use of teams and incentives to meet objectives negatively effect firm performance for the firms in the sample. Lastly, there exists no relationship between sharing information and firm performance.

In the research model, the association between HRMfirm strategy fit (alignment) and firm performance is also investigated. The findings reveal that there exists a positive relationship between HRM-firm strategy fit and firm performance. The findings regarding regression model exploring the effects of HR practices on HRM-firm strategy fit imply that there exist significant links between all five HR practices and HRMfirm strategy fit. The mediating effect of HRM-firm strategy fit should be investigated for larger samples in order to interpret its contribution on the relationship between HR practices and firm performance.

\section{Future Directions}

It should be pointed out that the restricted sample size as well as the manner in which it has been selected represents a limitation for this study. On the other hand, the attempt to clarify linkages between HR practices and organizational performance reflects an important area for ongoing research. There still exists questions regarding which HR practices diffuse more readily and why?. The importance of systematically aligning HR practices and organizational success and strategy hasn't been well established empirically (Bowen et all., 2002). Ideally, future studies would include data on firm performance to allow an assessment of the effectiveness of various strategy-HR practice bundles linkages. It may be useful for future HRM research to examine how different dimensions of HRM systems impact different outcomes.

\section{Managerial Implications}

The findings that selectively hiring positively effects organizational performance is considered as a significant practical insight for managers. Staffing and selection continues to be an area of significant interest (Wimbush, 2005). Recruitment and selection methods for effective hiring decisions are considered to be important for managers. High performing organizations tend to spend more time on training especially on communication and team skills (Lau, Ngo, 2004). The finding that there exists a positive link between training and firm performance is consistent with the human capital perspective. Therefore, we suggest that managers should develop training-focused HR practices to achieve competitive advantage.

Altogether the findings of this and other studies on issues related to human resource management provide theoretical and empirical evidence that HR practices can help organizations enhance organizational performance. 


\section{REFERENCES}

Baruch, Y., (1998), "Walking the Tightrope:

Strategic Issues for Human Resources", Long Range

Planning, 31(3); 467-475

Bawen, D.E., Galang, C., Pillai, R., (2002), "The role of human resource management: an explarotary study of cross country variance", Human Resource

Management 41(1), 103-122

Beatty, R.W.,Ewing, J.,R., and Tharp, G.G., (2003), "HR`s Role in Corporate Governance: Present and Prospective", Human Resource Management, 42(3), 257-269

Becker, B and Gerhart, B, (1996), "The Impact of Human Resource Management on Organizational Performance: Progress and Prospects", - The Academy of Management Journal, 39(4): 779-801

Delaney, J.T. and Huselid, M.A., (1996), "The Impact of Human Resource Management Practices on Perceptions of Organizational Performance", The Academy of Management Journal, 39 (4): 949-969

Enz, C A and Siguaw, J A (2000), 'Best Practice in Human Resources' Cornell Hotel and Restaurant Administration Quarterly, February, pp 48-61

Fahy, J., (2002), "A Resource Based Analysis of Sustainable Competitive Advantage In a Global Environment", International Business Review, 11 : 57-78

Fitzenz J., (1997), "The Truth About Best Practices: Why They are and How To Apply Them", Human Resource Management 36(1): 97-103

Galbreath, J., (2005), "Which resources matter most to firm success? An Explaratory Study of resourceBased Theory?", Technovation 25: 979-987

Gowen III., C.R. and Tallon W. (2005), "Effect of Technological Intensity on the Relationships Among Six Sigma Design, Electronic Busines, and Competitive Advantage: A dynamic Capabilities Model Study", Journal of High Technology Management Research, 16 : 59-87

Grundy, T.,(1997), "Human Resource Management-a Strategic Approach,", Long Range Planning, 30(4): 507- 517

Guest, D.E., (1997), "Human Resource Management and Performance: A Review and Research Agenda", International Journal of Human Resource

Management, $8: 263-276$

Harris, L. C. and Ogbonna, E., (2001), Strategic human resource management, market orientation, and organizational performance, Journal of Business Research 51, 157-166

Heijltjesa M. and Witteloostuijn A., (2003), Configurations of market environments, competitive strategies,manufacturing technologies and human resource management policies:A two-industry and two-country analysis of fit, Scand. J. Mgmt 19, 3162

Hiltrop, J.M., (1996), "The Impact of Human Resource Management on Oganizational Performance: Theory and Research", European Management Journal, 14(6():628-637

Hiltrop, J.M., (1999), "The Quest fort the Best: Human Resources Practices to Attract and Retain Talent", European Management Journal, 17(4): 422430

Huselid, M.A., (1995), "The Impact of Human Resource Management Practices on Turnover, Productivity, and Corporate Financial", The Academy of Management Journal, 38(3): 635-672

Huselid, M.A., (1997), "The Impact of High Performance Work Systems, Implementation Effectiveness, and Alignment with Strategy on Stakeholder Wealth", Submitted to 1997 Academy of Management Annual Meetings, Human Resource Management Division.

Jackson, S.E., Schuler, R.S. and Riviera, J.C., (1997), "Technical and Strategic Human Resource Management Efectiveness on Determinants of Firm Performance", Academy of Management Journal, 40(1): 171-188

Jayaram, J., Droge, C. and Vickery S. K, (1999), The impact of human resource management practices on manufacturing performance, Journal of Operations Management 18, 1-20

Kelliher, C. and Perrett, G., (2001), Business strategy and approaches to HRM: A case study of new developments in the United Kingdom restaurant industry", Personnel Review 30(4), 421-437.

Kippenberger, T, (1996), The missing link: human resources and business strategy, The Antidote 1(1) 
Lau, C.M. and Ngo, H.Y., (2004), "The HR system, organizational culture and product innovation"

International Business Review, 13: 685-703

Luoma, M.,( 2000)," Investigating the link between strategy and HRD" Personnel Review 29(6), 769-

790.

Milkovich, G., (1992), "Strengthening the Pay

Performance Relationship: The Research",

Compensation and Benefits Review, 24(6); 53-62

Offstein, E.H., Gynawali, D.R. and Cobb, A., T., (2005), "A Strategic Human Resource Perspective of Firm Competitive Behaviour", Human Resurce Management Review, 305-318

Pfeffer, J., (1998), The Human Equation: Building Profits By Putting People First, Boston, MA:

Harward Business School Press.

Roehling, M.V. Boswell, W.R. Caligiuri, P. and Feldman, D., (2005), "The Future Of $\mathrm{Hr}$ Management: Research Needs And Directions", Human Resource Management, 44(2): 207 - 216

Rogers, E. W. and White, P. M., (1998), Measuring organizational Performance in strategic human resource management: programs, prospects and performance information markets, Human Resource Management Review 8(3), 311-331

Terpstra D. E., (1994), "HRM: A Key to

Competitiveness", Management Decision 32 (9), 10-14

Tung-Chun Huang, "The effects of linkage between business and human resource management "Strategies Personnel Review, Vol. 30 No. 2, 2001, pp. 132-151.

Vale, R., Martin, F., Romero, P. M., and Dolan, S.L., (2000), "Business Strategy, work processes and human resource training: are they congruent?" Journal of Organizational Behaviour, 283-297

Werbel J.D. and DeMarie, S.M., (2005), "Aligning Strategic Human Rersource Management and Person Environment Fit", Human Resource Management review, 15: 242-262

Wimbush J.C. (2005), "Spotlight on human resource management", Human Resource Management, 48: 463-67

Wrifght, P.M., Mcmahan G., Gerhart, B. And Snell, S.A., (1997), "Strategic Human Resource
Management: Building Human Capital and Organizational Capability" Technical Report, Cornell University. 